\title{
ANALISIS FORECASTING JUMLAH KUNJUNGAN TAMU HOTEL DI KOTA BUKITITINGGI
}

\author{
Musli Yanto ${ }^{1)}$, Rini Sovia ${ }^{2)}$, dan Putri Melati ${ }^{3)}$ \\ ${ }^{1,2,3}$ Teknik Informatika, Fakultas Ilmu Komputer, Universitas Putra Indonesia YPTK \\ 1,2,3J1.Raya Lubuk Begalung, Padang, 25221 \\ E-mail : musli_yanto@upiyptk.ac.id ${ }^{1)}$,rini_sovia@upiyptk.ac.id ${ }^{2}$, putrimelati24061998@ gmail.com ${ }^{3)}$
}

\begin{abstract}
ABSTRAK
Bukittinggi merupakan salah satu kota yang dikenal dengan destinasi objek wisata. Beragam bentuk sajian wisata tersaji untuk para wisatawan yang berkunjung baik nasional maupun mancanegara. Salah satu fasilitas yang dibutuhkan oleh para pengunjung adalah ketersediaan hotel untuk tempat menginap saat melakukan kunjungan wisata. Pada penelitian ini, permasalahan yang akan dibahas adalah sebuah proses analisis forecasting untuk melihat jumlah kunjungan tamu hotel yang ada di kota Bukittinggi. Proses forecasting yang dilakukan ini menggunakan metode artificial neural network algoritma back propagation. Metode ini sangat cocok dalam melakukan sebuah proses forecasting , dimana metode ini bekerja dengan melakukan proses pelatihan dan pengujian terhadap pola data yang dibangun sebelumnya. Proses analisis forecasting tersebut dimulai dengan menemukan variabel data dan membangun pola jaringan terlebih dahulu berdasarkan data jumlah kunjungan tamu hotel serta variabel predictor yang digunakan diantaranya jumlah kunjungan wisata, jumlah objek wisata, inflasi dan nilai tukar rupiah. Proses ini menghasilkan hasil dengan tingkat nilai akurasi yang didapatkan sebesar $99.98 \%$ dan nilai kesalahan sebesar 0.002\%.Hasil tersebut didapat dari pola jaringan dengan bentuk 5-70-1 dimana pola tersebut merupakan pola jaringan terbaik yang didapat berdasarkan proses pelatihan dan pengujian jaringan. Hasil penelitian ini akan dijadikan bahan pertimbangan bagi pihak pengelola hotel serta pemerintah setempat dalam pengelolaan sektor pariwisata guna meningkatkan Pendapatan Asli Daerah (PAD) kota Bukittinggi.
\end{abstract}

Kata Kunci: Wisata, Kunjungan Forecasting, Artificial Neural Network, Back propagation, Pola Jaringan

\section{PENDAHULUAN}

Jumlah kunjungan tamu hotel pastinya tidak terlepas dengan jumlah kedatangan wisatawan yang terjadi pada sebuah daerah. Lebih $50 \%$ kunjungan tamu hotel berasal dari jumlah wisatawan. Hal ini membuat banyaknya para pengelola hotel untuk berlomba lomba dalam menyediakan fasilitas layanan menginap di tempat kawasan yang memiliki objek destinasi wisata. Tidak hanya itu, sektor pariwisata yang dikelola oleh pemerintah pun juga akan ikut berdampak terhadap jumlah kunjungan tamu hotel guna meningkatkan Pendapatan Asli Daerah (PAD).

Salah satu sumber pendapatan asli daerah ialah penerimaan pajak hotel. Pada penelitian yang sudah dilakukan sebelumnya menjelaskan bahwa, jumlah kunjungan wisata dan kunjungan tamu hotel sangat berpengaruh positif terhadap penerimaan pajak hotel, semakin tinggi jumlah akan kunjungan maka semakin tinggi penerimaan pajak Aliandi dan Handayani, (2013).Penelitian yang senada juga dilakukan oleh Pertiwi (2019), mengatakan bahwa jumlah wisatawan dan jumlah tingkat hunian hotel yang berbintang sangat mempengaruhi nilai angka pajak hotel sehingga juga akan mempengaruhi Pendapatan Asli Daerah (PAD).

Pada penelitian yang akan dilakukan ini, peneliti membahas sebuah proses analisis dalam melakukan forecasting jumlah kunjungan tamu hotel yang ada di kota Bukittinggi. Proses tersebut dilakukan untuk melihat tingkat kenaikan dan penurunan jumlah kunjungan tamu hotel yang nantinya akan mempengaruhi angka pendapatan pajak hotel. Dalam analisis forecasting ini, peneliti menggunakan metode Artificial neural network (ANN) untuk menghasilkan angka jumlah kunjungan tamu hotel pada periode berikutnya.

Berdasarkan penelitian sebelumnya, artificial neural network dapat melakukan proses forecasting pada kunjungan tamu hotel non bintang dengan cukup akurat dan menghasilkan hasil yang optimal (Sihotang dan Wanto, 2018). Penelitian yang sejalan sudah dilakukan yang menjelaskan bahwa jaringan saraf tiruan atau yang disebut juga dengan artificial neural network mampu memprediksi jumlah reservasi kamar hotel dengan hasil lebih akurat (Yanto, dkk, 2015).

Dalam melakukan analisis forecasting terhadap jumlah kunjungan tamu hotel yang ada di kota Bukittinggi ini, algoritma yang digunakan dalam metode artificial neural network adalah back propagation. Algoritma ini dirasa sangat cocok dalam melakukan proses forecasting .

Dalam penelitian dengan topik dan tema yang sama, dimana algoritma back propagation dalam melakukan proses prediksi jumlah kedatangan wisata mancanegara mampu menghasilkan tingkat akurasi hasil yang sangat tinggi (Yanto, dkk, 2020). Penelitian yang sudah 
dihasilkan dalam penggunaan algoritma back propagation dalam forecasting dengan topik lainnya juga menjelaskan bahwa algoritma ini sangat cocok dan mampu dalam memprediksi data dengan baik terutama data yang berkelanjutan dalam jangka waktu tertentu (Wanto, 2019). Pada penelitian lainnya juga menjelaskan bahwa algoritma back propagation memiliki keunggulan pada nilai learning rate. Nilai tersebut sangat berguna dalam menentukan hasil prediksi dengan eror yang kecil. Dengan menggunakan metode ini, tingkat akurasi data yang paling besar (Khotimah dan Lynda, 2014).

Pada penelitian ini, dapat dilihat berdasarkan pembahasan yang dilakukan memiliki kelebihan dari beberapa penelitian sebelumnya. Perbedaan yang terlihat berdasarkan penelitian sebelumnya dalam prediksi jumlah reservasi kamar hotel, di sini penulis hanya terfokus pada jumlah reservasi saja tanpa melihat asal dan tujuan dari tamu hotel tersebut. Dalam penelitian ini, penulis mengambil variabel sudah mencakup aspek kedatangan tamu hotel berdasarkan kunjungan wisata serta faktor apa saja yang dapat dijadikan penilaian dalam melihat tinggi rendahnya angka kunjungan pada sebuah daerah.

Proses analisis forecasting dengan artificial neural network algoritma back propagation ini bertujuan untuk menemukan angka jumlah kunjungan yang akan terjadi dan nantinya akan digunakan sebagai proses pertimbangan dalam mengelola sektor pariwisata di kota Bukittinggi yang dilihat dari tingkat hunian hotel. Tujuan lainnya dalam penelitian ini juga memberikan masukan kepada pemerintah daerah guna mendukung kegiatan dalam meningkatkan tata kelola dari sektor pariwisata. Manfaat yang didapat dari penelitian ini adalah hasil forecasting ini dapat dijadikan data pembanding dengan data jumlah kunjungan yang terjadi pada waktu periode yang ditentukan guna melihat keakuratan dari hasil forecasting yang dihasilkan.

\section{RUANG LINGKUP}

Permasalahan dalam penelitian ini adalah bagaimana proses analisis forecasting dapat dilakukan guna melihat jumlah kunjungan tamu hotel yang aka terjadi pada periode berikutnya. Batasan dalam penelitian ini adalah melakukan proses analisis forecasting dengan menggunakan metode artificial neural network algoritma back propagation serta variabel yang digunakan dalam pembentuk pola jaringan adalah sebagai berikut:

X1 = Jumlah kunjungan Wisata Mancanegara

$\mathrm{X} 2$ = Jumlah kunjungan Wisata Nasional

X3 = Jumlah Objek Wisata

$\mathrm{X} 4$ = Inflasi

X5 = Kurs Rupiah

$\mathrm{T}$ = Target Keluaran Jaringan

Setelah variabel dalam proses forecasting didapat, tujuan yang akan dihasilkan dari hasil penelitian ini adalah untuk menghasilkan pola jaringan yang terbaik yang nantinya digunakan dalam proses forecasting jumlah kunjungan tamu hotel di kota Bukittinggi.
Sehingga manfaat yang akan didapat dalam penelitian ini dapat membantu pihak yang terkait yakni pihak manajemen hotel serta pemerintah daerah dalam mengelola sektor pariwisata.

\section{BAHAN DAN METODE}

Metode penelitian yang digunakan adalah metode kuantitatif, dimana metode ini melakukan proses perhitungan berdasarkan algoritma dengan variabel data. Pembahasan proses analisis forecasting yang akan dilakukan dapat dilihat dalam kerangka penelitian yang ada di dalam Gambar1 Kerangka Dan Tahapan Penelitian.

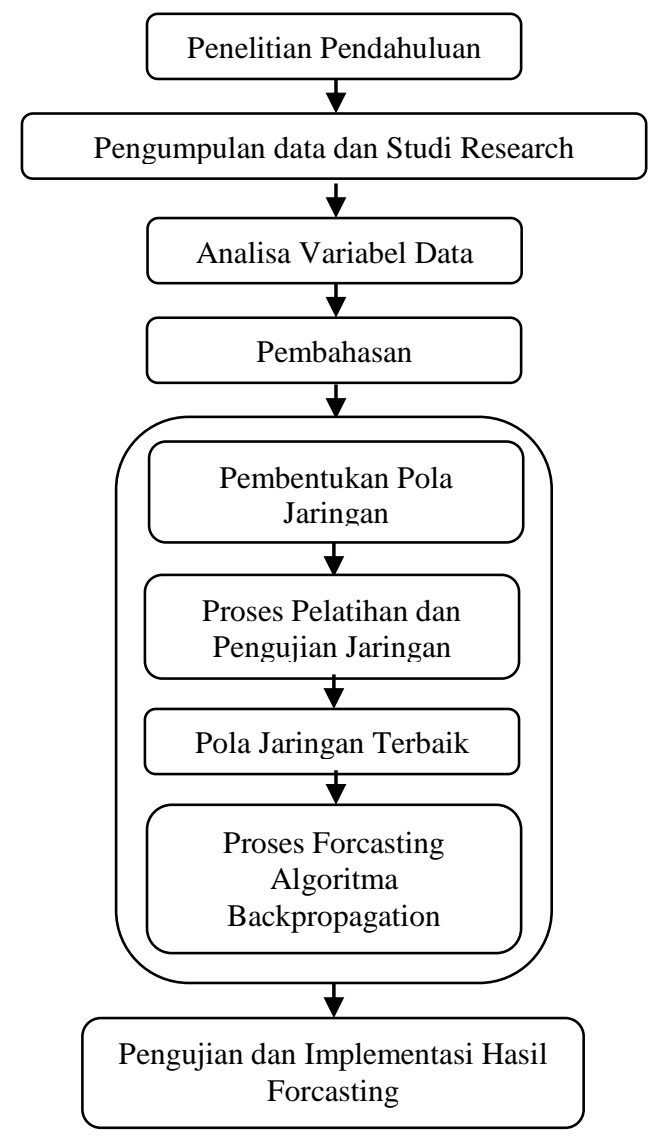

Gambar 1. Kerangka dan Tahapan Penelitian

Dalam kerangka dan tahapan penelitian yang terlihat pada gambar1, merupakan aliran aktivitas penelitian yang akan dijelaskan sebagai berikut:

\subsection{Penelitian Pendahuluan}

Tahapan ini merupakan proses dalam menentukan ruang lingkup dari penelitian dalam membahas proses analisis forecasting dan juga menjelaskan tujuan serta manfaat yang akan dihasilkan dari penelitian ini.

\subsection{Pengumpulan data dan Studi Research}

Data yang digunakan dalam penelitian ini bersumber dari Badan Pusat Statistik (BPS) Provinsi Sumatera 
Barat, dimana data tersebut akan dijadikan variabel dalam melakukan proses forecasting. Selain data yang didapat pada tahapan ini, penulis juga mempelajari beberapa penelitian sebelumnya yang memiliki kaitan erat dalam topik pembahasan yang akan dilakukan. Dalam tahapan ini, teori yang menjadi landasan ilmiah.

\subsubsection{Artificial neural network}

Artificial neural network (ANN) atau jaringan saraf tiruan (JST) adalah sistem pemroses informasi yang memiliki karakteristik mirip dengan jaringan saraf biologi manusia. Jaringan saraf tiruan dibentuk sebagai generalisasi model matematika dari pemahaman manusia (human cognition) (Ardana, 2017).

Jaringan saraf tiruan (ANN) merupakan salah satu representasi tiruan dari otak manusia yang selalu mencoba untuk menyimulasikan proses pembelajaran pada otak manusia tersebut. Otak manusia berisi berjutajuta sel saraf (neuron) yang bertugas untuk memproses informasi. Masing-masing sel saling berinteraksi sehingga mendukung kemampuan kerja otak. Setiap sel saraf akan memiliki satu inti sel yang bertugas untuk melakukan pemrosesan informasi (Hadihardaja, I.K. dan Sugeng, S., 2015).

Jaringan Saraf Tiruan (JST) merupakan suatu sistem pemrosesan informasi yang mempunyai karakteristik menyerupai jaringan saraf biologis (JSB) Jaringan Saraf Tiruan tercipta sebagai suatu generalisasi model matematis dari pemahaman manusia (human cognition) (Wuryandari, M.D.I.A. 2012) •

\subsubsection{Algoritma Back propagation}

Back propagation merupakan algoritma pembelajaran yang terawasi dan biasanya digunakan oleh perceptron dengan banyak lapisan untuk mengubah bobot-bobot yang terhubung dengan neuron-neuron yang ada pada lapisan tersembunyi. Algoritma back propagation menggunakan error output untuk mengubah nilai bobotbobotnya dalam arah mundur (backward). Untuk mendapatkan error ini, dilakukan dengan proses tahap perambatan maju (forward propagation) harus dikerjakan terlebih dahulu (Hadihardaja, I.K. dan Sugeng, S., 2015).

Jaringan saraf tiruan back propagation merupakan salah satu model dari jaringan saraf tiruan umpan maju dengan menggunakan pembelajaran terawasi yang disusun berdasarkan pada algoritma error back propagation yang didasarkan pada aturan pembelajaran koreksi kesalahan (error correction learning rule). Arsitektur jaringan saraf tiruan back propagation terdiri dari unit masukan, unit layer tersembunyi dan unit keluaran. Algoritma jaringan saraf tiruan back propagation dapat dibagi ke dalam dua bagian, yaitu (Sovia, dkk, 2016):

1. Algoritma pelatihan, terdiri dari tiga tahap yaitu tahap umpan maju pola pelatihan input, tahap mempropagasi balikkan error dan tahap pengaturan bobot.
2. Algoritma aplikasi atau pengujian yang digunakan hanyalah umpan maju saja.

Untuk lebih jelasnya akan dijelaskan langkahlangkah algoritma back propagation sebagai berikut (Sovia, dkk, 2016):

Langkah 0 : inisialisasi bobot dengan bilangan acak kecil.

Langkah 1 : jika kondisi penghentian belum terpenuhi, lakukan langkah 2-9.

Langkah 2 : untuk setiap pasang pada data pelatihan, lakukan langkah 3-8

Langkah 3 : tiap unit masukan menerima sinyal dan meneruskannya ke unit tersembunyi di atasnya.

Langkah 4 : hitung semua keluaran di unit tersembunyi Langkah 5 : Pada setiap unit di lapisan tersembunyi $z_{j}$ (dari unit ke-1 sampai unit ke-n ke-p; $i=1, \ldots \ldots, n ; j=l, \ldots . p$ ) sinyal output lapisan tersembunyi dihitung dengan menerapkan fungsi aktivasi terhadap penjumlahan sinyal-sinyal input berbobot $x_{i}$ pada (1):

$$
Z_{j}=f\left(V o_{j}+\sum X_{I} V_{i j}\right)_{i=1}^{n}(1)
$$

Langkah 6 : Setiap unit di lapisan outputy $_{k}$ (dari unit ke-1 sampai unit ke-m; $\mathrm{i}=1, \ldots . \mathrm{n} ; \mathrm{k}=1, \ldots . . \mathrm{m}$ ) dihitung sinyal output-nya dengan menerapkan fungsi aktivasi terhadap penjumlahan sinyal-sinyal input berbobot $Z_{j}$ bagi lapisan ini pada (2).

$$
\left.Y=f\left(w_{o k}^{2}\right)+\sum Z_{j} W_{j k}\right)_{i=1}^{p}
$$

Langkah 7 : Setiap unit outputYk (dari unit ke-1sampai

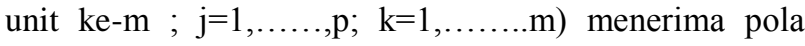
target $t k$ lalu informasi kesalahan lapisan output ( $\delta$ ) dihitung $\delta_{\mathrm{k}}$ dikirim ke lapisan di bawahnya dan digunakan untuk menghitung besar koreksi bobot dan bias $\left(\Delta \mathrm{w}_{\mathrm{jk}}\right.$ dan $\left.\Delta \mathrm{w}_{\mathrm{ok}}\right)$ antara lapisan tersembunyi dengan lapisan output pada (3).

$\delta_{K}=\left(\mathrm{t}_{\mathrm{k}}-\mathrm{y}_{\mathrm{k}}\right) \mathrm{f}^{\prime}$

$$
\Delta W_{j k}=\alpha \delta_{k} Z_{j}
$$

$\Delta W_{0 k}=\alpha \delta_{k}$

Langkah 8 : Pada setiap unit di lapisan tersembunyi (dari unit ke-1 sampai unit ke- $p ; i=1, \ldots ., n ; j=1 \ldots . . p ; k=1 \ldots . \mathrm{m}$ ) dilakukan perhitungan informasi kesalahan lapisan tersembunyi $\left(\delta_{j}\right) . \quad \delta_{j}$ kemudian digunakan untuk menghitung besar koreksi bobot dan bias $\left(\Delta \mathrm{V}_{\mathrm{ij}}\right.$ dan $\left.\Delta \mathrm{V}_{\mathrm{oj}}\right)$ antara lapisan input dan lapisan tersembunyi pada (4).

$$
\begin{aligned}
\delta j & =\left(\sum \delta k W_{j k}\right)_{k=1}^{m} f^{\prime}\left(V_{o j}+\sum X_{i} V_{i j}\right)_{i=1}^{n} \\
\Delta V_{i j} & =\alpha \delta_{j} X_{i} \\
\Delta V_{0 j} & =\alpha \delta_{j}
\end{aligned}
$$

Tahap Perubahan bobot dan bias

Langkah8: Pada setiap unit output $Y k$ (dari unit ke-1 sampai unit ke-m) dilakukan perubahan bias dan bobot $(j=0, \ldots, p ; k=1, \ldots ., m)$ sehingga bias dan bobot yang baru menjadi pada (5). $W_{j k}($ baru $)=W_{j k}($ lama $)+\Delta V i j(5)$ 
dari unit ke-1 sampai unit ke-p di lapisan tersembunyi juga dilakukan perubahan pada bias dan bobotnya $(i=0, \ldots, n ; j=1, \ldots, p)$ pada $(6)$.

$$
V_{j k}(\text { baru })=W_{j k}(\text { lama })+\Delta V i j(6)
$$

Langkah 10 : Tes kondisi berhenti

\subsection{Analisis Variabel Data}

Tahapan ini menjelaskan data yang akan digunakan dalam proses forecasting perlu dilakukan analisis terlebih dahulu. Proses ini dimulai dengan melihat keterkaitan data dengan hasil yang dihasilkan dari proses forecasting terhadap jumlah kunjungan tamu hotel di Kota Bukittinggi.

\section{PEMBAHASAN}

Pembahasan dalam penelitian ini adalah proses analisis forecasting terhadap jumlah kunjungan tamu hotel. Berikut proses pembahasan yang akan dilakukan:

\subsection{Proses Analisis Data}

Penelitian dalam proses pembahasan analisis forecasting ini, penulis terlebih dahulu melakukan tahapan analisis data. Adapun data kunjungan wisata dan tamu hotel yang digunakan dalam penelitian ini dapat dilihat pada Tabel 1.

Tabel 1. Data Kunjungan Wisata dan Tamu Hotel

\begin{tabular}{|l|c|c|c|}
\hline \multirow{2}{*}{ Bulan } & \multicolumn{2}{|c|}{ Jumlah Kunjungan } & \multirow{2}{*}{$\begin{array}{c}\text { Jumlah } \\
\text { Tamu Hotel }\end{array}$} \\
\cline { 2 - 3 } & $\begin{array}{c}\text { Wisatawan } \\
\text { Mancanegara }\end{array}$ & $\begin{array}{c}\text { Wisatawan } \\
\text { Nasional }\end{array}$ & \\
\hline Januari & 2610 & 38860 & 3 \\
\hline Pebruari & 3115 & 25310 & 3 \\
\hline Maret & 2935 & 30878 & 3 \\
\hline April & 2917 & 22121 & 3 \\
\hline Mai & 2890 & 20105 & 3 \\
\hline J u n i & 3707 & 40664 & 3 \\
\hline J u 1 i & 4805 & 39614 & 3 \\
\hline Agustus & 3811 & 37454 & 3 \\
\hline September & 4558 & 55124 & 3 \\
\hline Oktober & 5311 & 56560 & 3 \\
\hline November & 3847 & 57166 & 3 \\
\hline Desember & 5225 & 92627 & 3 \\
\hline
\end{tabular}

Setelah data kunjungan wisata dan tamu hotel, maka variabel data yang juga akan digunakan dalam proses forecasting dapat dilihat pada Tabel 2.
Tabel 2.Variabel data

\begin{tabular}{|c|c|c|c|c|c|}
\hline $\mathrm{X} 1$ & $\mathrm{X} 2$ & $\mathrm{X} 3$ & $\mathrm{X} 4$ & $\mathrm{X} 5$ & $\mathrm{~T}$ \\
\hline 2610 & 505555 & 3 & 3.25 & 13480 & 38860 \\
\hline 3115 & 87827 & 3 & 3.18 & 13776 & 25310 \\
\hline 2935 & 265236 & 3 & 3.4 & 13825 & 30878 \\
\hline 2917 & 379164 & 3 & 3.41 & 13946 & 22121 \\
\hline 2890 & 324031 & 3 & 3.23 & 14021 & 20105 \\
\hline 3707 & 1010083 & 3 & 3.12 & 14476 & 40664 \\
\hline 4805 & 600659 & 3 & 3.18 & 14485 & 39614 \\
\hline 3811 & 313466 & 3 & 3.2 & 14785 & 37454 \\
\hline 4558 & 269508 & 3 & 2.88 & 15004 & 55124 \\
\hline 5311 & 301148 & 3 & 3.16 & 15303 & 56560 \\
\hline 3847 & 296024 & 3 & 3.23 & 14411 & 57166 \\
\hline 5225 & 609435 & 3 & 3.13 & 14553 & 92627 \\
\hline
\end{tabular}

\subsection{Proses Transformasi Data}

Setelah variabel data didapat, data tersebut akan ditransformasikan ke dalam bentuk bilangan biner dengan mengaktifkan fungsi aktivasi sigmoid biner dengan interval data [0.1] dan [0.9]. Adapun rumus transformasi yang digunakan dapat dilihat pada (7) .

$$
\mathrm{Y}=\frac{0.8(X-X \min )}{X \max -X \min }+0.1
$$

Proses transformasi data terhadap variabel data yang ada akan dilakukan perhitungan dengan7, berikut hasil dari proses transformasi data yang dihasilkan dapat dilihat pada Tabel 3 .

Tabel 3.Hasil Transformasi Data

\begin{tabular}{|c|c|c|c|c|c|}
\hline $\mathrm{X} 1$ & $\mathrm{X} 2$ & $\mathrm{X} 3$ & $\mathrm{X} 4$ & $\mathrm{X} 5$ & $\mathrm{~T}$ \\
\hline 0.1021 & 0.5004 & 0.1000 & 0.1000 & 0.1107 & 0.1308 \\
\hline 0.1025 & 0.1696 & 0.1000 & 0.1000 & 0.1109 & 0.1200 \\
\hline 0.1023 & 0.3101 & 0.1000 & 0.1000 & 0.1109 & 0.1245 \\
\hline 0.1023 & 0.4003 & 0.1000 & 0.1000 & 0.1110 & 0.1175 \\
\hline 0.1023 & 0.3566 & 0.1000 & 0.1000 & 0.1111 & 0.1159 \\
\hline 0.1029 & 0.9000 & 0.1000 & 0.1000 & 0.1115 & 0.1322 \\
\hline 0.1038 & 0.5757 & 0.1000 & 0.1000 & 0.1115 & 0.1314 \\
\hline 0.1030 & 0.3483 & 0.1000 & 0.1000 & 0.1117 & 0.1297 \\
\hline 0.1036 & 0.3135 & 0.1000 & 0.1000 & 0.1119 & 0.1437 \\
\hline 0.1042 & 0.3385 & 0.1000 & 0.1000 & 0.1121 & 0.1448 \\
\hline 0.1030 & 0.3345 & 0.1000 & 0.1000 & 0.1114 & 0.1453 \\
\hline 0.1041 & 0.5827 & 0.1000 & 0.1000 & 0.1115 & 0.1734 \\
\hline
\end{tabular}

\subsection{Pembentukan Pola Jaringan Forecasting}

Data yang sudah ditransformasikan berdasarkan variabel yang digunakan, maka proses akan dilanjutkan untuk membentuk pola jaringan dalam melakukan analisis forecasting . Berikut bentuk pola jaringan yang dapat dilihat pada gambar 2 . 


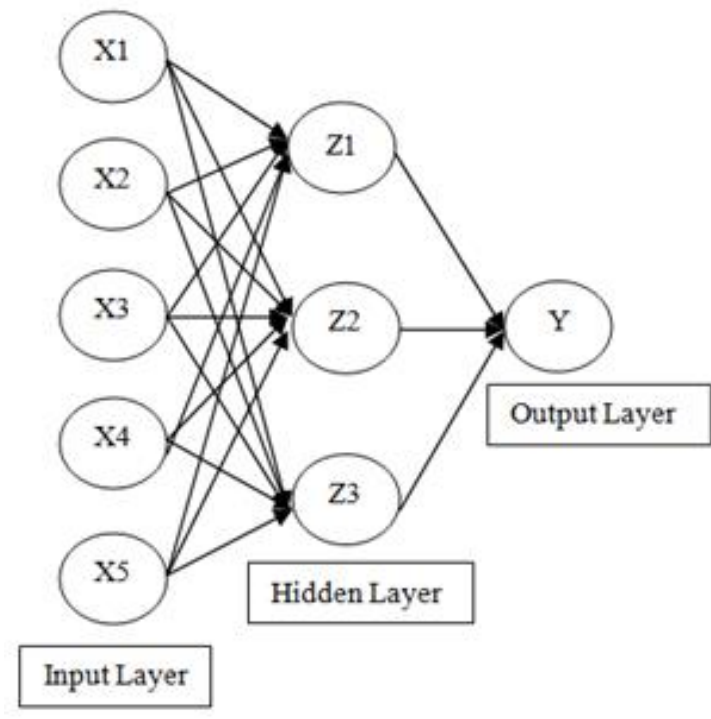

Gambar 2. Pola Jaringan Forecasting

Pola jaringan yang sudah dibentuk akan digunakan dalam proses pelatihan dan pengujian guna melihat dan mengukur nilai akurasi yang diberikan berdasarkan keluaran jaringan.

\subsection{Proses Pelatihan dan Pengujian Jaringan}

Proses pelatihan dan pengujian dalam penelitian ini dibantu dengan menggunakan software MATLAB. Software ini nantinya akan melakukan proses pelatihan dan pengujian dengan sistem perhitungan yang telah diperintahkan dalam sebuah bahasa pemrograman. Adapun hasil proses pelatihan dan pengujian yang didapat dilihat pada Tabel 4 Hasil Proses Pelatihan dan Tabel 5 Hasil Proses Pengujian.
Tabel 4. Hasil Proses Pelatihan

\begin{tabular}{|c|c|c|c|c|}
\hline $\mathbf{T}$ & $\mathbf{Y}$ & Error & Performance & MSE \\
\hline 0.1308 & 0.6242 & -0.4934 & 0.2999 & -0.53477 \\
\hline 0.1200 & 0.8636 & -0.7436 & 4.5375 & 2.010483 \\
\hline 0.1245 & 0.6638 & -0.5393 & 0.8968 & 0.1225 \\
\hline 0.1175 & -0.3588 & 0.4763 & 1.544 & 0.715017 \\
\hline 0.1159 & 0.7126 & -0.5967 & 2.6054 & -0.72015 \\
\hline 0.1322 & 0.4915 & -0.3593 & 3.8549 & -1.31303 \\
\hline
\end{tabular}

Tabel 5.Hasil Proses Pengujian

\begin{tabular}{|c|c|c|c|c|}
\hline $\mathbf{T}$ & $\mathbf{Y}$ & Error & Performance & MSE \\
\hline 0.1314 & -1.3261 & 1.4575 & 2.9174 & 1.587883 \\
\hline 0.1297 & 0.7989 & 0.9286 & 1.8191 & 1.075283 \\
\hline 0.1437 & -1.8519 & 1.9956 & 0.3593 & 0.140983 \\
\hline 0.1448 & -2.5635 & 2.7083 & 2.4903 & -0.89088 \\
\hline 0.1453 & -0.7339 & 0.8792 & 1.937 & 0.706567 \\
\hline 0.1734 & -1.3847 & 1.5581 & 4.0373 & -1.2254 \\
\hline
\end{tabular}

\subsection{Perbandingan Pola Jaringan}

Berdasarkan proses pelatihan dan pengujian yang telah dilakukan, hasil dari pola jaringan ini masih memiliki nilai kesalahan besar dari nilai keluaran jaringan yang dihasilkan. Sehingga jika digunakan dalam proses forecasting pastinya tidak akan menghasilkan keluaran yang tingkat akurasi rendah. Maka dari itu proses akan dilanjutkan untuk menemukan pola jaringan yang terbaik berdasarkan perbandingan pola jaringan. Berikut hasil perbandingan pola jaringan yang dilakukan guna menghasilkan pola jaringan yang terbaik dapat dilihat pada Tabel 6 Hasil Perbandingan Pola Jaringan.

Tabel 6.Hasil Perbandingan Pola Jaringan

\begin{tabular}{|c|c|c|c|c|c|}
\hline \multirow{2}{*}{ Pola } & \multicolumn{2}{|c|}{ MSE } & \multicolumn{2}{c|}{ MAPE } & \multirow{2}{*}{ Akurasi } \\
\cline { 2 - 5 } & Pelatihan & Pengujian & Pelatih & Pengujia & \\
\hline $5-7-1$ & -0.5348 & 1.5879 & -0.0385 & 0.0152 & 99.95 \\
\hline $5-14-1$ & 2.0105 & 1.0753 & 0.0102 & 0.0224 & 100.01 \\
\hline $5-21-1$ & 0.1225 & 0.1410 & 0.1680 & 0.1711 & 101.69 \\
\hline $5-28-1$ & 0.7150 & -0.8909 & 0.0288 & -0.0271 & 99.97 \\
\hline $5-35-1$ & -0.7202 & 0.7066 & -0.0286 & 0.0341 & 100.02 \\
\hline $5-42-1$ & -1.3130 & -1.2254 & -0.0157 & -0.0197 & 100.12 \\
\hline $5-49-1$ & -0.8156 & -0.5446 & -0.0252 & -0.0443 & 100.02 \\
\hline $5-56-1$ & 0.5978 & -1.8646 & 0.0344 & -0.0129 & 100.01 \\
\hline $5-63-1$ & 0.5903 & -1.8646 & 0.0349 & -0.0129 & 100.01 \\
\hline $5-70-1$ & -7.0804 & 1.2389 & -0.0029 & 0.0195 & 99.98 \\
\hline
\end{tabular}

Hasil perbandingan yang didapat, maka pola jaringan terbaik dapat ditemukan dan akan digunakan dalam proses analisis forecasting terhadap jumlah kunjungan tamu hotel.

\subsection{Proses Forecasting Kunjungan Tamu Hotel}

Pola jaringan yang terbaik didapat dengan pola jaringan dengan bentuk 5-70-1. Dari pola tersebut, pada Tabel 6 , terlihat bahwa jaringan dengan pola ini memiliki nilai MSE sebesar 0.016 dan nilai MAPE sebesar 0.0195 serta nilai tingkat akurasi hasil keluaran jaringan sebesar 99.98\%. Berdasarkan pola ini proses analisis dilakukan guna melihat hasil yang didapat dalam proses forecasting jumlah kunjungan tamu hotel. Adapun hasil analisis forecasting yang dilakukan dapat dilihat pada Tabel 7 Hasil Proses analisis Forecasting . 
Tabel 7. Hasil Proses Analisis Forecasting

\begin{tabular}{|c|c|c|}
\hline Data & T & Y_net \\
\hline 1 & 0.1308 & 0.1328 \\
\hline 2 & 0.1200 & 0.1185 \\
\hline 3 & 0.1245 & 0.1282 \\
\hline 4 & 0.1175 & 0.0912 \\
\hline 5 & 0.1159 & 0.1379 \\
\hline 6 & 0.1322 & 0.1324 \\
\hline 7 & 0.1314 & 0.1314 \\
\hline 8 & 0.1297 & 0.1289 \\
\hline 9 & 0.1437 & 0.1439 \\
\hline 10 & 0.1448 & 0.1447 \\
\hline 11 & 0.1453 & 0.1454 \\
\hline 12 & 0.1734 & 0.1734 \\
\hline
\end{tabular}

Setelah hasil keluaran didapat, maka hasil tersebut akan diubah kembali dalam bentuk keluaran data dengan menggunakan rumus dinormalisasi dan pada akhirnya hasil keluaran jaringan tersebut dapat dilihat serta digunakan oleh pihak yang terkait.

\section{KESIMPULAN}

Dalam penelitian ini, proses analisis forecasting yang dilakukan dengan menggunakan metode artificial neural network algoritma back propagation mampu menghasilkan hasil yang baik untuk menunjukkan angka jumlah kunjungan tamu hotel berdasarkan pola jaringan yang dengan bentuk 5-70-1. Hasil forecasting yang didapat memiliki tingkat nilai akurasi yang cukup tinggi sebesar 99,98\% dan tingkat kesalahan yang dihasilkan sebesar $0.02 \%$ serta nilai MAPE dengan total keseluruhan sebesar 0.0195. Proses analisis yang dihasilkan dapat digunakan nantinya sebagai sumber data untuk melihat jumlah kunjungan tamu hotel yang akan terjadi pada periode berikutnya. Hasil ini juga sangat bermanfaat bagi pemerintah setempat dalam pengelolaan sektor pariwisata yang ada di Kota Bukittinggi khususnya mengelola ketersediaan hotel sebagai fasilitas tempat menginap bagi wisatawan. Sehingga pihak pemerintah dapat meningkatkan pendapatan asli daerah (PAD) dari hasil pajak hotel yang dihasilkan.

\section{SARAN}

Untuk penelitian selanjutnya, dalam melakukan forecasting terutama dalam melihat jumlah kunjungan tamu hotel, disarankan untuk menambah variabel predictor lain yang nantinya akan dapat mempengaruhi ataupun berdampak pada angka kenaikan dan penurunan jumlah kunjungan. Kemudian lakukan lebih banyak lagi percobaan dalam melakukan perbandingan pola guna menghasilkan pola jaringan yang lebih baik.

\section{DAFTAR PUSTAKA}

Aliandi, V.D.A. dan Handayani, H.R., 2013. Pengaruh Jumlah Wisatawan, Jumlah Hotel, Dan Tingkat Hunian Hotel Terhadap Penerimaan Pajak Hotel (Studi Kasus Pada Kota Yogyakarta), Diponegoro Journal Of Economics Volume 2, Nomor 4.

Ardana, P.D.H. 2017, Artificial neural network Dalam Hidrologi, Jurnal Ilmiah Teknik Sipil.

Hadihardaja, I.K. dan Sugeng, S., 2015. Pemodelan Curah Hujan-Limpasan Menggunakan Artificial neural network (ANN) dengan Metode Back propagation, Jurnal Teknik Sipil, Vol.12, No.3.

Khotimah, B.K. dan Suryaningtias, L.O., 2014. Prediksi Loyalitas Pelanggan Hotel Dengan Menggunakan Metode Back propagation, Prosiding Seminar Nasional Manajemen Teknologi XX.

Pertiwi, A.C. 2019. Pengaruh Jumlah Wisatawan Dan Hotel Terhadap Pendapatan Asli Daerah Kabupaten/Kota Di Provinsi Daerah Istimewa Yogyakarta Tahun 2012-2018, Jurnal Akuntansi Tahun 2019. Universitas Ahmad Dahlan.

Sovia, R., Yanto, M., \& Nursanty, W. 2016, Implementation Of Signature Recognition By Using Back propagation, UPI YPTK Journal of Computer Science and Information Technology.

Sihotang, B.K. dan Wanto, A., 2018. Analisis JST Dalam Memprediksi Jumlah Tamu Pada Hotel NonBintang, Jurnal Techno.COM, Vol. 17, No. 4.

Sovia, R., Yanto, M. dan Nursanty, W., 2016, Implementation Of Signature Recognition By Using Back propagation, UPI YPTK Journal of Computer Science and Information Technology.

Wanto, A., 2019. Prediksi Produktivitas Jagung Indonesia Tahun 2019-2020 Sebagai Upaya Antisipasi Import Menggunakan Jaringan Saraf Tiruan Back propagation, Jurnal Sintech, Vo 1. 1 No. 1.

Wuryandari, M.D.I.A. 2012. Perbandingan Metode Jaringan Syaraf Tiruan Back propagation Dan Learning Vector Quantization Pada Pengenalan Wajah. Jurnal Komputer dan Informatika (KOMPUTA), Edisi. I Volume. 1.

Yanto, M, Sovia, R. dan Melati, P., 2020. Prediksi Jumlah Kunjungan Wisata dengan Algoritma Back propagation, Jurnal Media Informatika Budidarma,Vo.4,No.2

Yanto, M., Devit, S. dan Nurcahyo, G.W., 2015.Analisis Jaringan Syaraf Tiruan Untuk Memprediksi Jumlah Reservasi Kamar Hotel Dengan Metode Back propagation (Studi Kasus Hotel Grand Zuri Padang), Jurnal KomTekInfo Fakultas Ilmu Komputer, Volume 2, No. 1. 